\title{
Post-harvest losses of crops and its determinants in Ethiopia: tobit model analysis
}

\author{
Sisay Debebe*
}

\begin{abstract}
Background: Reduction of post-harvest loses of crops are crucial tasks in ensuring food and nutrition security. However, a lack of knowledge on the extent of post-harvest losses and its associated impeding factors are posing major challenges to effectiveness of grain post-harvest loss management strategy and to scale up for all other crop types in Ethiopia. The study estimates the magnitude of post-harvest losses of all crops and identifies its determinants.

Methodology: A national-level agriculture survey data were obtained from the Central Statistical Agency of Ethiopia. Data were analyzed using descriptive statistics and Tobit model analysis techniques.

Results: The analysis shows $25.81 \%$ perceived annual average post-harvest losses of crops were obtained with considerable variation across the crop types. The main factors impeding post-harvest losses of crops were households with larger adult family size, higher levels of education attendance, and wealth status, large landholding size and damage of stored crops by insect pests infestation and/or rodent feeding due to utilization of traditional storage equipments, access to extension support services, cooperative marketing membership, and being far away from both all weathered roads and near local market centers due to a higher transaction costs associated with a lack of market information, contamination, and mechanical injuries.

Conclusion: Minimization of post-harvest losses of crops could be achieved through a holistic approach by providing short and long-term training on post-harvest management practices, promoting the use of post-harvest technologies, paying special attention to the institutional support systems (agriculture extension and rural credit services), strengthening the support for post-harvest handling technologies, reinforcing the existing farmer cooperative marketing, and improvements of the local market and road networking infrastructures of rural areas should be undertaken by the government in collaboration with non-government organizations.
\end{abstract}

Keywords: Post-harvest losses of crops, Determinants, Tobit model, Ethiopia

\section{Background}

Ethiopia with 110 million people is the second-most populous country in sub-Saharan Africa [34]. The majority of its population depends on agriculture for income and livelihood. The sector, as is the case in most African countries, still remains the backbone of the economy. It accounts for about $32.7 \%$ of the total GDP, contributes $84 \%$ of total export, serves as more than $70 \%$ of sources

*Correspondence: sisaydebebe2000@gmail.com; sisay.debebe@aau.edu.et Department of Economics, Addis Ababa University, Addis Ababa, Ethiopia of raw material for agro-processing industry, and it also employs more than $73 \%$ of the employment opportunities and source of livelihoods for $90 \%$ of the population residing in rural areas [30, 10, 20,35]. Moreover, the sector has been contributing to the attainments of the country's objectives trajectory to become a middle-income economy by the year 2025 . However, realizing the selfsufficiency in food still calls active involvement of both government and development partners.

Over the last years, both the government and nongovernmental organizations (NGOs) have implemented various development interventions aiming for original author(s) and the source, provide a link to the Creative Commons licence, and indicate if changes were made. The images or other third party material in this article are included in the article's Creative Commons licence, unless indicated otherwise in a credit line to the material. If material is not included in the article's Creative Commons licence and your intended use is not permitted by statutory regulation or exceeds the permitted use, you will need to obtain permission directly from the copyright holder. To view a copy of this licence, visit http://creativecommons.org/licenses/by/4.0/. The Creative Commons Public Domain Dedication waiver (http://creativeco mmons.org/publicdomain/zero/1.0/) applies to the data made available in this article, unless otherwise stated in a credit line to the data. 
transforming the agriculture sector and thereby achieving food self-sufficiency in the country. The government gives special attention to agriculture development in its all development strategy plans. In 2001/2 Sustainable Development and Poverty Reduction Plan (SDPRP) [23], the Rural Development Policy and Strategies in 2003 [24], subsequently in 2005/05 Plan for Accelerated and Sustainable Development to End Poverty [25], in 2009/10 Growth Transformation Plan-I (GTP-I) [26] and an extension to the latter in 2015/16 GTP-II was implemented and considered the agriculture sector as one of the major growth drivers of the economy [27]. Despite the fact that all development plans gave emphasis on the improvements of agriculture production and productivity and fostering commercialization, only the recent GTP-II plan gave specific attention for minimization of post-harvest losses of crops and thereby ensuring food security in the country. In view of this, the government specifically designed and implemented the Post-harvest Management Strategy (PMS) in 2016 for grain crops to reduce post-harvest loss from 25 to $5 \%$ by 2020 . In addition, the government has been working hard towards the achievements of international stated goals such as the 2014 agreements of the Malabo Declaration of Africa Union (halve postharvest loss by 2025) and 2030 global targets of SDGs (end poverty and hunger) [21].

Despite such policy focus, the country remains far below stated post-harvest loss targets. According to recent studies, the estimated average magnitudes of postharvest loss in Ethiopia ranges from 15.5 to $27.2 \%$ for major grain crops [28] and 23\% average loss for all crops [21]. A post-harvest loss contributes to the reduction of food supply and, hence, leads to high food prices in the market and thereby aggravating the food insecurity situation in the country. The main reasons of post-harvest loss among others is inherent weaknesses in post-harvest handling techniques due to the poor management practices, lack of infrastructure and appropriate equipments and limited access to market $[11,28]$. In response to this, a number of cost effective post-harvest handling management techniques and technologies such as hermetic plastic bags (PIOS, AgroZ, and Yabi bags, and metal silos) were introduced by government in collaboration with development partners. However, the limited focus in scope of the PMS to grain crops only also pave difficulties [21]. Therefore, the reduction of post-harvest losses of all crops could be considered as a viable strategy for improving livelihoods of farmers and releasing the pressure on the environment. This needs a depth understanding on where and why the post-harvest losses of crops occur and thereby helps for providing a sustainable solution to the problems.
Previous empirical studies on post-harvest losses examined the causes, challenges, opportunities for reduction of post-harvest losses of crops and its implication on food insecurity in Ethiopia [17, 9, 18, 31, 32]. While these studies conducted in different parts of the country for different types of crops, they did not utilize econometric model estimation technique using national-level representative data for all stages, and hence, it creates difficulties for understanding the severity of problems and its associated effects at the national level. In contrast, there are some other few studies attempted to quantify the magnitude of post-harvest losses of major grain crops at various stages of post-harvest management practices in different parts of Ethiopia [11, 15, 4, 13, 28]. They all reported a higher significant proportion of post-harvest losses of major grain crops in their respective studies. In addition, they are a few other empirical review studies done at the national level such as Abrehet [1] and Dubale [8] in which syntheses the previous empirical studies. Such type of study is not only essential for creating awareness on the implications of post-harvest losses of crops on food security but also provides input for the effectiveness of PMS, direct future needful strategies, policies, and programs in the country. However, studies on the post-harvest losses of all crops using econometrics model and national-level representative data are scant in Ethiopia. In view of the above facts, this study was undertaken with the objectives of measuring the magnitude and identifies the factors impeding post-harvest losses of all crops using national-level agriculture survey data in Ethiopia. The remaining part of the article describes the methodology, the main findings and discussions, and conclusion of the study.

\section{Methodology}

\section{Data type, sources and sampling design}

Secondary agriculture survey data were used from Central Statistical Agency (CSA) of Ethiopia. The sampling frame covered population from all rural areas of Ethiopia. The survey was carried out in 2020 considering the outputs of crops for 2018/19 production season, and was designed in such a way that represent all regions including Amhara, Oromia, SNNPR (Southern Nation and Nationalities Region), and Tigray regional states of Ethiopia. The survey included 3,830 national-level representative farmers that are selected from all regions of the country [7].

\section{Method of data analysis}

In this study, the magnitude of perceived post-harvest losses of crops was estimated for all crops (such as cereals, pulse, oilseed, fruit, and vegetables). In the first phase, the status of post-harvest losses of crops was 
determined. In the second stage, the extent of postharvest losses of crops estimated by asking the estimated perceived post-harvest losses of all crops during production, field drying, transportation, winnowing, packaging, and storage of harvest crops. The concept of calculating perceived post-harvest loss is also applied by other researches in similar studies such as Hengsdijk and de Boer [15] and Bachewe et al. (4).

Tobit model is used when the status neither yes nor no, and extent or magnitude of post-harvest loss are assumed to be influenced jointly or factors affecting them are assumed to be the same. Moreover, Tobit model is more applicable in truncated distribution of observations in the data set. In this study, perceived post-harvest loss of crops status has censored distributions due to the fact that a large number of farmers encountered post-harvest losses of crops. The censored distribution is a combination of continuous and discrete distributions because of the mass of observations at zero. Since the latent variable has a normal distribution, strictly positive values of perceived post-harvest loss status have a continuous distribution. The probability associated with latent variable values below or equal to the censoring point is summed to a single discrete value. Thus, the Tobit model uses all of the information, including information on censoring and provides consistent estimates [6, 14].

The model was developed by Tobin [33] and perceived post-harvest loss observed for values greater than 0 , i.e., for perceived post-harvest crop loss, but is not observed, i.e., censored or no perceived post-harvest crop loss for values of 0 or less. Accordingly, the model is specified as

$$
Y_{*}=\left\{\begin{array}{l}
Y_{i}^{*} \text { if } Y_{i}^{*}>0 \\
0 \text { if } Y_{i}^{*} \leq 0
\end{array},\right.
$$

where $Y$ is the observed variable and $Y_{i}^{*}$ is the latent variable which is the perceived post-harvest crop loss and is explained by the following equation:

$$
Y_{i}^{*}=\beta X_{i}+\mu_{i}
$$

where $X_{i}$ is the observed demographic, socio-economic, farm-specific attributes, marketing and institutional variable and $\beta$ a vector of parameters and $\mu_{i}$ is a normally distributed error term which is a normally distributed with zero and constant variance of $\sigma^{2}$ which is explained by $\mu_{i} \sim \mathrm{N}\left(0, \delta^{2}\right)$.

Based on McDonald and Moffit [22], three marginal effects of the model are specified as follows:

i. The marginal effect on the latent variable (unconditional expected value):

$$
\frac{\partial E(Y / X)}{\partial X_{K}}=\beta_{K} \Phi\left(\frac{X \beta}{\sigma}\right) .
$$

ii. The marginal effect on the expected value of observations conditional on being uncensored:

$$
\begin{aligned}
& \frac{\partial E(Y / X, Y>0}{\partial X_{K}} \\
& =\beta_{K}+\beta_{K} \frac{\partial \lambda(c)}{\partial c} \\
& =\beta_{K}[1-\lambda(c)(c+\lambda(c))]<\beta_{K},
\end{aligned}
$$

where $\lambda(c)$ is inverse mill's ratio.

iii. The marginal effect on the probability that observations are uncensored:

$$
\frac{\partial \operatorname{Pr}(Y>0 / X)}{\partial X_{K}}=\varphi\left(\frac{X \beta}{\delta}\right) \frac{\beta_{K}}{\delta} .
$$

\section{Results and discussion}

\section{Descriptive statistics results}

Cereals, pulses, oilseeds, fruit, and vegetable crops are important food crops widely cultivated in different parts of the country. The survey result estimated $25.81 \%$ annual average perceived post-harvest losses of all crops. The quantity of self-reported post-harvest loss varies with the types of crops. Fruit and vegetables take the lead to the first by taking $33.38 \%$ of post-harvest loss. Cereal crops, the second and it take $23.36 \%$ of post-harvest loss. Pulses and oilseed the third and account $23.25 \%$ post-harvest loss during the cropping seasons. Moreover, as shown in Table 1, from the total interviewed farmers, $64.83 \%$ $(2,483)$ encountered post-harvest losses of crops while the remaining $35.17 \%(1,347)$ did not perceive post-harvest losses of crops during the year.

Table 1 reports the mean or proportion values of the demographic, socio-economic, farm-specific, institutional, and marketing variables which are hypothesized to influence perceived post-harvest losses of crops. The result of the comparison for demographic and socioeconomic characteristics shows that the average size of a household member was 3.84 in adult equivalence, 4.7 years of education attendance and 0.29 wealth indexes. Besides, farmers who did not encountered perceived post-harvest losses of crops have significantly higher mean household size (4.04), levels of education attendance (4.97) and wealth index (0.57) as compared to those who did not with average household size (3.73), level of education attendance (4.65), and wealth index (1.37) and all are statistically significant with a mean the difference at $1 \%$ level of significance. 
Table 1 Independent variables by perceived post-harvest losses of crops status

\begin{tabular}{|c|c|c|c|c|}
\hline \multirow[t]{2}{*}{ Variables } & \multirow{2}{*}{$\begin{array}{l}\text { Total } \\
(n=3830) \\
\% \text { (frequency) or mean } \\
\text { (St. dev.) }\end{array}$} & \multirow{2}{*}{$\begin{array}{l}\text { Post-harvest loss } \\
(n=2483) \\
\% \text { (frequency) or mean } \\
\text { (St. dev.) }\end{array}$} & $\begin{array}{l}\text { No loss } \\
(n=1347)\end{array}$ & \multirow[t]{2}{*}{$\chi^{2}$ or $t$-test } \\
\hline & & & $\begin{array}{l}\text { \% (frequency) or mean } \\
\text { (St. dev.) }\end{array}$ & \\
\hline \multicolumn{5}{|l|}{ Demographic characteristics } \\
\hline $\begin{array}{l}\text { Sex of the household head } \\
\text { ( } \% \text { male of total) }\end{array}$ & $50.52(1,935)$ & $51.62(999)$ & $48.37(936)$ & 7.55 \\
\hline Household size-adult equivalent scale & $3.84(1.94)$ & $3.73(1.920)$ & $4.04(1.993)$ & $-4.716^{* * *}$ \\
\hline \multicolumn{5}{|l|}{ Socio-economic characteristics } \\
\hline Education level一years & $4.70(2.35)$ & $4.56(2.33)$ & $4.97(2.37)$ & $-5.226^{* * *}$ \\
\hline Total wealth index & $0.29(0.39)$ & $1.37(1.67)$ & $0.57(5.09)$ & $-1.297^{* * *}$ \\
\hline \multicolumn{5}{|l|}{ Farm-specific attributes } \\
\hline Total landholding size in hectare & $1.54(0.64)$ & $1.39(1.92)$ & $1.82(5.34)$ & $-2.191^{* * *}$ \\
\hline Insect pests infestation and/or rodent_-dummy & $87.78(3,362)$ & $7.17(241)$ & $92.83(3,121)$ & $-3.14^{* * *}$ \\
\hline Availability of storage-dummy & $34(1,302)$ & $51.07(665)$ & $48.92(637)$ & 5.85 \\
\hline \multicolumn{5}{|l|}{ Institutional and marketing characteristics } \\
\hline Extension support services—dummy & $55.69(2,133)$ & $34.89(744)$ & $65.11(1,389)$ & $-3.11^{* * *}$ \\
\hline Cooperative membership_dummy & $39.11(1,498)$ & $40.65(609)$ & $59.34(889)$ & $-3.03^{* * *}$ \\
\hline Use of credit_dummy & $14(535)$ & $49.53(265)$ & $39.53(262)$ & 6.32 \\
\hline Distance to all weathered road, $\mathrm{km}$ & $14.34(21.55)$ & $15.85(27.96)$ & $13.52(17.04)$ & $3.201^{* * *}$ \\
\hline Distance to nearest main market, $\mathrm{km}$ & $59.74(47.30)$ & $66.20(52.48)$ & $56.24(43.85)$ & $6.253^{* * *}$ \\
\hline
\end{tabular}

Source: Own computation based on CSA 2020 survey data

Comparison of farm-specific attributes explained in Table 1, the result shows the average landholding size was 1.54 hectare. Farmers who did not perceive post-harvest losses of crops have significantly higher mean landholding size 1.82 hectare as compared to others with a mean landholding size (1.39). Moreover, from the total $87.78 \%$ of farmers encountered insect pests infestations and/ or rodent feeding on their storage of crops, the proportion is significantly higher among farmers who perceived post-harvest losses of crops (92.83\%) than others with $(7.17 \%)$ and a statistically significant proportion difference at a $5 \%$ level of significance.

In Table 1, the result of comparison for the institutional and marketing characteristics shows that the proportion of farmers who have taken extension support services related to post-harvest loss minimization techniques $(65.11 \%)$ and farmers who are a member of cooperative marketing (34.89\%) was significantly higher among farmers who perceived post-harvest losses of crops than others and statistically significant proportion differences at a $1 \%$ level of significance. Moreover, the average distance from home to all weathered road was $14.34 \mathrm{~km}$ and to the nearest local the market center was $59.74 \mathrm{~km}$. Farmers who did not perceive post-harvest crop losses of crops on averaged traveled a longer distance to all weathered road $(15.85 \mathrm{~km})$ and local market center $(66.20 \mathrm{~km})$ and both are statistically significant with a mean difference at a $1 \%$ level of significance.
In Table 1, the result of comparison for the institutional and marketing characteristics shows that the proportion of farmers who have taken extension support services related to post-harvest loss minimization techniques (65.11\%) and farmers who are a member of cooperative marketing (34.89\%) was significantly higher among farmers who perceived post-harvest losses of crops than others and statistically significant proportion differences at a $1 \%$ level of significance. Moreover, the average distance from home to all weathered road was $14.34 \mathrm{~km}$ and to the nearest local the market center was $59.74 \mathrm{~km}$. Farmers who did not perceive post-harvest crop losses of crops on averaged traveled a longer distance to all weathered road $(15.85 \mathrm{~km})$ and local market center $(66.20 \mathrm{~km})$ and both are statistically significant with a mean difference at a $1 \%$ level of significance.

\section{Econometrics model result}

Tobit model results in Table 2 shows that the estimation of $\mathrm{F}$ statistics with a value of 13 is statistically significant at a $1 \%$ level of significance, implying the adequacy of the model to estimate the relationship between the dependent and the selected independent variables. Further, the variables included in the model were tested for the problems of multicollinearity, heteroskedasticity, and model misspecification. As suggested by Arabmazer and Schmidt [2], the problem of multicollinearity was checked using Variance Inflating Factor (VIF) and 
Table 2 Tobit model result and their marginal effects

\begin{tabular}{|c|c|c|c|c|c|}
\hline \multirow[t]{2}{*}{ Variables } & \multirow[t]{2}{*}{ Coefficient } & \multirow[t]{2}{*}{ Std. error } & \multicolumn{3}{|l|}{ Marginal effects } \\
\hline & & & $\begin{array}{l}\text { Unconditional } \\
\text { expected value }\end{array}$ & $\begin{array}{l}\text { Conditional } \\
\text { uncensored }\end{array}$ & $\begin{array}{l}\text { Probability } \\
\text { uncensored }\end{array}$ \\
\hline \multicolumn{6}{|l|}{ Demographic characteristics } \\
\hline Sex of the household head & 0.26 & 1.705 & 0.1843 & 0.1298 & 0.0022 \\
\hline Household size (adult equivalent) & $-0.91^{* *}$ & 0.437 & -0.6401 & -0.4511 & -0.0077 \\
\hline \multicolumn{6}{|l|}{ Socio-economic characteristics } \\
\hline Education level in years & $-0.26^{*}$ & 0.144 & -0.1807 & -0.1273 & -0.0022 \\
\hline Total wealth index & $-0.075^{* * *}$ & 0.023 & -0.0531 & -0.0374 & -0.0006 \\
\hline \multicolumn{6}{|l|}{ Farm-specific attributes } \\
\hline Total land holding size in hectare & $-0.129^{* * *}$ & 0.047 & -0.0913 & -0.0643 & -0.0011 \\
\hline Insect infestation and/or rodent attack & $0.01^{* *}$ & 0.002 & 0.0026 & 0.0018 & 0.0001 \\
\hline Availability of storage (dummy) & 0.79 & 2.037 & 0.5590 & 0.3939 & 0.0067 \\
\hline \multicolumn{6}{|l|}{ Institutional and marketing characteristics } \\
\hline Extension support services & $-5.55^{* *}$ & 2.199 & 3.9137 & -2.7579 & -0.0472 \\
\hline Cooperative membership & $-0.38^{* *}$ & 0.166 & -0.2642 & -0.1862 & -0.0032 \\
\hline Use of credit & 0.85 & 2.377 & 0.6024 & 0.4245 & 0.0073 \\
\hline Distance to nearest main market & $0.07^{* * *}$ & 0.009 & 0.0489 & 0.0344 & 0.0006 \\
\hline Distance to all weathered road & $0.25^{* *}$ & 0.107 & 0.1760 & 0.1240 & 0.0021 \\
\hline Constant & $35.12^{* * *}$ & 6.719 & & & \\
\hline Log likelihood & -9309.29 & & & & \\
\hline$F(12,2474)$ & $13^{* * *}$ & & & & \\
\hline Left-censored observations & 808 & & & & \\
\hline Uncensored observations & 1678 & & & & \\
\hline Right-censored observations & 0 & & & & \\
\hline
\end{tabular}

Source: Model Result

the mean value of VIF was found to be 1.19 indicating less degree of collinearity among explanatory variables. Following Breusch and Pagan [5], the problem of test heteroskedasticity problem was conducted BreuschPagen test $\left(\lambda^{2}=0.58, P=04,475\right)$ the result implying homoscedasticity in the of the error term. Moreover, the model misspecification was carried out using Ramsey's regression specification error test (RESET), and the results revealed with value of Ramsey test $(F=0.78$, $P=0.4563$ ) indicating that no omitted relevant variables in the model. Finally, the results of the model show that all coefficients of the variables hypothesized to influence post-harvest losses of crops have the expected sign and of the 12 variables included in the model, and 9 are found to have statistically significant effects on the status and extents of post-harvest losses of crops.

\section{Discussions}

\section{Demographic characteristics}

Family size (in terms of adult equivalent) in the household has a negatively and significantly influenced the status and extents of post-harvest losses of crops at $1 \%$ level of significance, indicating farmers with more adult family size was less likely encountered post-harvest losses of crops. This is due to the fact that most of the post-harvest activates is a labor-intensive requiring a number of adult people. The various activities include: prompt harvesting, timely drying of crops, winnowing, packaging, and transportation to storage of harvested crops. A $1 \%$ increase in adults' family size in the households would lead to $64.0 \%$, $45.11 \%$, and $0.77 \%$ decreases in the unconditional (considering all observation), conditional (considering uncensored observation), and the probability of the proportion of post-harvest losses of crops, respectively (Table 2). The relationship between family size and post-harvest loss of grain crops was also obtained a similar result by Bachewe et al. [4].

\section{Socio-economic characteristics}

The average years of education of the household head have negatively and significantly affected the status and extents of post-harvest losses of crops at $10 \%$ levels of significance, implying household head who attended more education level in years better understand and implement agriculture instruction, grasp written material, and able to integrate the technical skills with the tacit local 
knowledge of post-harvest management practices. Thus, a higher educational level attendance of the household head in years suggests as important factor in decreasing the status and extents of post-harvest losses of crops. A $1 \%$ increase in the level of education of the household head in years would lead to $18.07 \%, 12.73 \%$, and $0.22 \%$ decreases in the unconditional, conditional, and probability of the proportion of post-harvest losses of crops, respectively (Table 2). This is consistent with the research result of Hodges et al. [16] and attendance of school till secondary education level by Shee et al. [29], Bachewe et al. [4], and Tadesse et al. [32]. The size of household wealth index has negatively and significantly affected the status and extents of post-harvest losses of crops at $1 \%$ level of significance, indicating being wealthier was less likely encountered post-harvest losses of crops. This is due to the fact that wealthier farmer get the required finance for purchasing various post-harvest handling technologies such as hermetic metal silo and Purdue improved crop storage bag. This is might also indicate the provision of rural credit services for post-harvest handling purposes might also rectify the shortage of finance for poor farmers. A $1 \%$ increase in the wealth index would lead to $5.31 \%, 3.74 \%$, and $0.06 \%$ decreases in the proportion of unconditional, conditional, and probability of post-harvest losses of crops, respectively (Table 2). A study by Bachewe et al. [4] also obtained a similar result in their studies.

\section{Farm-specific attributes}

The size of a farm in hectare has negatively and significantly affected the status and extents of post-harvest losses of crops at a 5\% level of significance, implying farmer households who own relatively large farm size was encountered less post-harvest losses of crops than others. This is due to large farm size owners farmers produce more production and, hence, earn adequate income for purchasing the various post-harvest handling technologies. A $1 \%$ increase in the size of a farm in hectare would lead to $9.13 \%, 6.43 \%$, and $0.11 \%$ decreases in the unconditional, conditional, and probability of proportion of post-harvest losses of crops, respectively (Table 2). However, some other studies such as Magingxa et al. [19] and Taddesse et al. [32] found a positive relationship between landholding size and post-harvest losses on various crops. They explained their reason farmers who have large farm size might face various constraints related to post-harvest handling practices such as shortage of storage and its facilities. Damage by insect pests' infestations and/or rodent feeding while storage has negatively and significantly affected the status and extents of post-harvest losses of crops at $5 \%$ levels of significance, implying farmers who face damage to insect pests' infestations and/or rodent feeding during storage encountered postharvest losses of crops compared to those farmers who did not. This is probably due to poor storage management and facilities, and inadequate knowledge of disease control methods. The farmers who face damage of insect pests infestations and/or rodent feeding during storage as compared with those who did not would lead to $0.26 \%, 0.18 \%$, and $0.01 \%$ increase of the unconditional, conditional, and probability of the proportion of postharvest losses of crops, respectively (Table 2). A significant amount of post-harvest losses of crops occurred due to rodents/pests/insects attack on storage $[8,16,15]$.

\section{Institutional and marketing characteristics}

Extension support service is given to the farmer in response to reducing post-harvest losses of crops has negatively and significantly affected the status and extents of post-harvest losses of crops at $5 \%$ levels of significance. The result implies farm households who receive extension support service less likely encountered post-harvest losses of crops than those who did not receive extension support services. This is because the extension support services given to farmers via development workers and/ or non-governmental organizations (such as SG2000 and FOA) have an important role in creating awareness and providing training on post-harvest loss of minimization techniques. Some of such techniques include cultivation of diseases resistant crops, prompt harvesting, proper drying of crops before storage, and techniques of treatments of crops with pesticides during the storage. Farmers who receive extension services as compared with those who did not would lead to $91.37 \%$, $75.79 \%$, and $4.72 \%$ decreases in the unconditional, conditional, and probability of the proportion of post-harvest losses of crops, respectively (Table 2). A similar study was also confirmed by FOA [11]. Farmers' membership in cooperative marketing has negatively and significantly affected the status and extents of post-harvest losses of crops at $5 \%$ levels of significance, implying farmers who are members of cooperative marketing less likely encountered post-harvest losses of crops. This is probably because the farmer who is a member of cooperative marketing gets an advantage of additional resource related to storage and transportation of their production to the market. A farmer who is a member of farmer cooperative marketing as compared with who did not would lead to $26.42 \%$, $18.62 \%$, and $0.32 \%$ decreases in the unconditional, conditional, and probability of the proportion of harvested crop losses, respectively (Table 2). Distance from the nearest local the market in kilometer has positively and significantly affected the status and extents of postharvest losses of crops at $1 \%$ level of significance, indicating farmers who live far away from the nearest local 
market more likely encountered post-harvest losses of crops. This is due to a higher transaction costs associated with a lack of market information, contamination, and mechanical injuries associated with the longer distance travel to supply to the market, and hence, the magnitude of losses increases especially for fruits and vegetable. A $1 \%$ increase in the distance to the nearest local market in kilometer would lead to $4.89 \%, 3.44 \%$, and $0.06 \%$ decreases in the unconditional, conditional, and probability of the proportion of post-harvest losses of crops, respectively (Table 2 ). Similar results were also obtained by Hengsdijk and de Boer [15], Gilbert et al. [12], Kasso et al. [17], and Tadesse et al. [32]. Distance from the nearest all weathered road in kilometer has positively and significantly affected the status and extents of post-harvest losses of crops at a 5\% level of significance, indicating farmers who live far away from the nearest all weathered road more likely encountered post-harvest losses of crops. The higher losses of crops might be occurred during transportation of their produce to the market using pack animals (donkey or horse cart), mini-track, and/ or own labor (carrying sacks). A $1 \%$ increase in the distance to the nearest local market in kilometer would lead to $17.6 \%, 12.4 \%$, and $0.21 \%$ increases in the proportion of the unconditional, conditional, and probability of postharvest losses of crops, respectively (Table 2). A similar result also obtained by Arah et al. [3], Emana et al. [9], Hengsdijk and de Boer [15] in their respective studies.

\section{Conclusions}

Reduction of post-harvest losses of crops between farm and market is crucial tasks to minimize the food gaps and thereby to ensure food and nutrition security in Ethiopia. However, a lack of understanding of the extent and associated contributing factors are posing major challenges for the effective implementation of grain post-harvest loss management strategies and to scale up for all other crop types in Ethiopia. Therefore, this study aims for assessing the extent and determinants of post-harvest losses of all crops in Ethiopia. Both descriptive and Tobit econometrics model were applied using large-scale national-level representative agriculture survey data from CSA of Ethiopia. The result shows $25.81 \%$ annual average perceived post-harvest losses of crops was obtained with considerable variation across the crop types. The magnitude of post-harvest losses of crops is first for fruit and vegetables (33.38\%), second for cereals (23.36\%) and third for pulse and oilseed crops (23.25\%). Post-harvest losses of crops were affected by the socio-economic, farm-specific, institutional and marketing factors. Among socioeconomic variables are the households with larger family sizes, higher education attendance, and being wealthier. Farm-specific variables include households with large landholding size and damage of insect pests' infestation and/or rodent attack during storage of harvested crops. Institutional and marketing variables include households who receive extension support services related to postharvest management practices, cooperative marketing membership, and being far away from both all weathered roads and near the local market center. Therefore, minimization of post-harvest losses of crops contribute to the achievements of national (GTP-II) and international (Malabo Declaration and SDGs) targets and thereby achieving food security could be mentioned via a holistic approach. The approach calls active involvements of the national and/or regional government in collaboration with privet and NGOs-development partners. These activities include providing short- and long-term training on postharvest management practices in general and particularly on the application of post-harvest handling technologies which helps for reducing the damage of stored crops by insect pests infestation, rodents feeding and mould contamination, strengthening the existing institutional support system (agricultural extension and credit services) by paying special attention to the public and privet investment on the use of post-harvest loss management practices, strengthening the government efforts of supplying post-harvest technologies in various means such as leaving a duty-free tax, providing subsidies and financial support for local industries as stated on PMS, reinforcing the existing farmer cooperative marketing, and improving both the local market and road networking infrastructure of rural areas of the country. In addition, the focus of grain post-harvest management strategy of the country should be scaled up to all types of crops.

Finally, this research suggested some possible areas for future researchers: the study applied CSA data and measured post-harvest loss by asking the estimated perceived quantitative post-harvest losses of crops considering 2019/20 cropping season production. It could be better to measure the magnitude of post-harvest losses as suggested by FOA [11] methodologies and also be good to estimate separately the magnitude and identify associated impeding factors for each post-harvest activity to provide specific policy recommendations.

\section{Abbreviations \\ CSA: Central Statistical Authority; FDRE: Federal Democratic Republic of Ethiopia; FOA: Food and Agriculture; MANR: Ministry of Agriculture and Natural Resources; MoFED: Ministry of Finance and Economic Development; PMS: Post-harvest Management Strategy; SDGs: Sustainable Development Goals; UN: United Nations.}

\section{Acknowledgements}

The author duly acknowledged CSA of Ethiopia for providing the data for the study.

Authors' contributions Not applicable. 


\section{Funding}

Not applicable.

\section{Availability of data and materials}

The datasets used and/or analyzed in the study will be available from the authors on reasonable request and approval of CSA of Ethiopia.

\section{Declarations}

Ethical approval and consent to participate

The author received the consent of CSA of Ethiopia to use the data for academic purpose.

\section{Consent for publication}

Not applicable.

\section{Competing interests}

The authors declare that they have no competing interests.

Received: 13 October 2020 Accepted: 10 January 2022

Published online: 06 February 2022

\section{References}

1. Abrehet FG. Post-harvest loss vs food and nutrition Insecurity: challenges and Strategies to overcome in Ethiopia. Int J Food Sci Nutr Eng. 2018;8(4):95-102. https://doi.org/10.5923/j.food.20180804.02.

2. Arabmazer A, Schmidt P. An investigation of the robustness of the Tobit estimation to non-normality. Econometric. 1984;50:1055-63.

3. Arah IK, Kumah EK, Anku EK, Amaglo H. An overview of post-harvest losses in tomato production in Africa: causes and possible prevention strategies. J Biol Agric Healthcare. 2015;5(16):13.

4. Bachewe F, Bart M, Alemayehu ST, Karl P, Alethia C, Tirsit GE. Farmers' grain storage and losses in Ethiopia. J Agric Food Ind Organ. 2020;18(1):1-19.

5. Breusch TS, Pagen AR. Simple test for heteroscedasticity and random coefficient variation. Econometirca. 1979;47(5):1287-94.

6. Cameron C, Trivedi PK. Micro econometrics. Using stata. College Station: State Press; 2009.

7. Central Statistics Agency. Integrated survey on agriculture: Central Statistical Agency, Addis Ababa, Ethiopia; 2020.

8. Dubale B. Postharvest losses in Ethiopia and opportunities for reduction: a review. IJSBAR. 2018;38(1):249-62.

9. Emana B, Afari-Sefa V, Nenguwo N, Ayana A, Kebede D. Characterization of Pre- and postharvest losses of tomato supply chain in Ethiopia. Agric Food Secur. 2017;6:3. https://doi.org/10.1186/s40066-016-0085-1.

10. Ethiopian Economics Association (EEA). Report on the Ethiopian Economy. EEA, Addis Ababa, Ethiopia; 2018.

11. FOA. Postharvest loss assessment of maize, wheat, sorghum and haricot bean: a study conducted in fourteen elected Woredas of Ethiopia under the Project-GCP/ETH/084/SWI, Addis Ababa, Ethiopia; 2017.

12. Gilbert CL, Christiaensen L, Kaminski J. Food price seasonality in Africa: measurement and extent. Food Policy. 2017;67:119-32. https://doi.org/ 10.1016/j.foodpol.2016.09.016.

13. Gebre A, Kerie Z, Bosha T, Desalegn T, Teklegiorgis Y. Post-harvest losses and handling practices of durable and perishable crops produced in relation with food security of households in Ethiopia: secondary data analysis. Stored Prod Postharvest Res. 2018;7(5):45-52. https://doi.org/10. 5897/JSPPR2016.0205.

14. Greene W. Econometric analysis. 6th ed. Upper Saddle River: Prentice-Hall; 2012.

15. Hengsdijk $\mathrm{H}$, de Boer WJ. Post-harvest management and post-harvest losses of cereals in Ethiopia. Food Sec. 2017;9:945-58. https://doi.org/10. 1007/s12571-017-0714-y.

16. Hodges RJ, Buzby JC, Bennett B. Postharvest losses and waste in developed and less developed countries: Opportunities to improve resource use. J Agric Sci. 2011;149(S1):37-45. https://doi.org/10.1017/s0021859610000936.

17. Kasso M, Bekele A. A Post-harvest loss and quality deterioration of horticultural crops in Dire Dawa region, Ethiopia. J Saudi Soc Agric Sci. 2016. https://doi.org/10.1016/j.jssas.2016.01.005.
18. Kumera N, Yetenayet B, Ali M, Eneyew T. Postharvest handling practices and on farm estimation of losses of sesame (Sesamum indicum L.) seeds: the case of two Wollega zones in Ethiopia. East Afr J Sci. 2020;14(1):23-38.

19. Magingxa $L L$, Alemu $Z G$, Van Schalwyk HD. Factors influencing access to produce markets for smallholder irrigators in South Africa. Dev South Afr. 2009;26(1):47-58.

20. NBE (National Bank of Ethiopia). Annual Report 2019/20, the National Bank of Ethiopia, Addis Ababa, Ethiopia; 2020.

21. MANR (Ministry of Agriculture and Natural Resources). Postharvest management strategy in grains in Ethiopia, Addis Ababa, Ethiopia; 2018.

22. McDonald J, Moffitt R. The uses of Tobit analysis. Rev Econ Stat. 1980;62:318-21.

23. MoFED (Ministry of Finance and Economic Development). Ethiopia: Sustainable Development and Poverty Reduction Program. Addis Ababa, Ethiopia; 2002.

24. MoFED. The Rural Development Policy and Strategies. Addis Ababa, Ethiopia; 2003.

25. MoFED. Ethiopia: sustainable development and poverty reduction program (SDPRP). Addis Ababa, Ethiopia; 2005.

26. MoFED. Growth and transformation Plan-I (GTP) 2010/11-2014/15. Addis Ababa, Ethiopia; 2010.

27. MoFED. Growth and transformation Plan-II (GTP) 2015/16-2019/20. Addis Ababa, Ethiopia; 2015.

28. Mohammed A, Tadesse A. Review of major grains postharvest losses in Ethiopia and customization of a loss assessment methodology. USAID/ Ethiopia Agriculture Knowledge, Learning, Documentation and Policy Project, Addis Ababa; 2018

29. Shee A, Mayanja S, Simba E, Stathers T, Bechoff A, Bennett B. Determinants of postharvest losses along smallholder Producers maize and Sweet potato value chains: an ordered Probit analysis. Food Secur. 2019:11:1101-20. https://doi.org/10.1007/s12571-0119-00949-4.

30. Sisay D, Jema H, Degye G, Abdi KE. Technical, allocative, and economic efficiency among smallholder maize farmers in South-western Ethiopia: parametric approach. J Dev Agric Econ. 2015;7(8):283-92.

31. Tesfaye $\mathbf{W}$, Tirivayi $\mathrm{N}$. The impacts of postharvest storage innovations on food security and welfare in Ethiopia. Food Policy. 2018;75:52-62. https:// doi.org/10.1016/j.foodpol.2018.01.004.

32. Tadesse B, Bakala F, Mariam LW. Assessment of postharvest loss along potato value chain: the case of Shaka Zone, Southwest Ethiopia. Agric Food Secur. 2018;7:18. https://doi.org/10.1186/s40066-018-0158-4.

33. Tobin J. Estimation of relationships for limited dependent variables. J Econometr. 1958:26(1):24-36.

34. United Nations. 'Migration and population change: drivers and impacts' population facts. United Nations, Department of Economics and Social Affairs, Population Division; 2018.

35. World Bank; 2020. https://www.worldbank.org/en/country/ethiopia/ overview.

\section{Publisher's Note}

Springer Nature remains neutral with regard to jurisdictional claims in published maps and institutional affiliations.

Ready to submit your research? Choose BMC and benefit from

- fast, convenient online submission

- thorough peer review by experienced researchers in your field

- rapid publication on acceptance

- support for research data, including large and complex data types

- gold Open Access which fosters wider collaboration and increased citations

- maximum visibility for your research: over $100 \mathrm{M}$ website views per year

At BMC, research is always in progress.

Learn more biomedcentral.com/submissions 